\title{
THE INTERESTS AND RIGHTS OF NATIONALITY
}

\author{
By C. E. McGuIre, Ph.D., \\ Assistant Secretary, International High Commission.
}

An examination of the history of the idea of nationality and the study of the development of nationalism, especially in the nineteenth century, would permit the enumeration of many instances of the depression and restraint of nationality; and, on the other hand, it would not be easy to cite a single example of a nationalism unambitious further to expand and satisfied that it had fulfilled every legitimate aspiration. If by some magic formula we were able to reverse the position of the world's affairs and subordinate the vigorous and dominating nations of Europe to the weaker and oppressed, what assurance have we that the latter would not manifest the same callous disregard that now is alleged to characterize the former? Is it, therefore, nothing but a matter of cumulative community selfishness, and are we to desist from our search for an underlying principle of nationality and for sanctions upon which all nationalities may base their claims for recognition? We are depressed by the answer of history. Nevertheless, history in so far as it records the development of ideas and the attempt to give them practical form and effect must be our instructor. Let us, therefore, examine and classify what we may agree to be the main interests of nationality, testing each interest in the innumerable retorts which history offers us, and at the same time bearing in mind that however imperfectly it may interpret them in action, our race is capable of following its ideals with sustained intensity through long periods.

The commonly accepted factors of nationality may be stated as the following:

(a) Racial identity or a reasonable homogeneousness of race

(b) Identity of language

(c) Unity of religion

(d) A symmetrical and healthy development of commerce and industry

(e) A uniform theory of government

What do we mean by racial identity or a reasonable homo- 
geneity of race? There is abroad, especially in this country, a belief that without racial identity and homogeneity of origin and development the national spirit will not thrive and animate a people. It is true, those who are most apprehensive of the failure of the national spirit to guide and strengthen the United States have been alarmed by the fact that the population of the republic has been increased and is increasing, not through the expansion of the original racial element, but rather through the accretion of every branch of the Indo-European races and of many non-European branches. They labor breathlessly to bring about a fusion, an assimilation of these elements. They would welcome the greatest possible intermixture of race in order that the resultant product should find all its, constituent racial tendencies neutralized and subordinated to those of its environment. But the tragedy of the "melting pot" theory is not its ineffectiveness so much as its superfluity. The greatest peoples in history, those most conscious of their aspirations towards unity, and which stand out so strongly in Greece, in Rome, in Spain, in Germany, in Ireland, have had no racial identity or exclusiveness of origin. They have severally welcomed races as diverse as the Arab, the Celt, the Teuton, the Scandinavian, the Etruscan, the Thracian. The national spirit in each case has been strong enough to impose language and ways of living, religious outlook, unity of purpose and its own fervent conviction of identity upon the new elements, often not seeking to do it but rather repelling them. In such cases it has been an invariable rule that the fullest and freest contribution of racial talents and excellencies has determined the formula of the nation's success. This is not to say that prejudice and internal difficulty and strife have not existed, but rather to say that in spite of these obstacles and many more, the newer racial elements have been fused and assimilated if at all, not so much by the stamp of administration, as by the attracting power of a stronger character and higher standards of individual life.

The interest which we associated with identity of language is one that appears to the mind at the first consideration of nationality. Many difficulties in the way of the creation of a strong national state are removed by the existence of a common language understanding. The part of literature in molding and strengthening national feeling cannot be over-emphasized; and the influence of the daily press today in standardizing language must not be overlooked, 
even though it be less than one would expect in view of the ubiquity of the press. Again the national systems of education have served as an effective means for the development of a national feeling through uniform instruction in language and literature devised and imposed by a single authority. Business men, professional men and the journalistic fashioners of our ready-made opinions receive their higher literary training and their ability to set the standards of our speech in learned institutions where speculation on the duty of intense nationalism is indulged in with facility and in abundance. None the less, nations have grown great and national feeling has been intense and evenly distributed without uniform regard for language standards. Any of the great European nations will afford examples to those well acquainted with them of a surprising diversity of dialect and popular speech, to say nothing of bi-lingual Belgium and tri-lingual Switzerland, familiar for their profound sense of national unity. Even France and Germany and England would suffice, to say nothing of the radical language differences which prevail in Hungary, in Finland, in Russia and in Spain. I do not refer to separatist movements such as the Catalan, but to the many distinct dialects which make up any one of these countries, distinguished in our day for their thorough nationalism. At times the idea of nationality has survived when the nation has lost or nearly lost its language; English-speaking Ireland is hardly less conscious of its ineradicable distinctness than if only the Celtic tongue were heard within its shores. Ireland's ballads have had their widest influence in nourishing hope of freedom and memories of oppression, in their English translations; and the work of political parties has been done in English. Despite the apparent plasticity of the Jewish race it retains an amazing sense of its exclusiveness and aloofness often with but the faintest grip upon the common tongue of the race. Is there then an interest of language? History's answer seems to show unmistakably that the ideal of nationality involves the notion of a common tongue adorned and inspired with the literature which properly expresses the hopes and aspirations of the people. But history shows too that this incidental notion of identity of language is but a rare element in assisting to achieve the freest development of nationality. Apparently nations can get on very well with a variety of dialects so long as superior interests of association keep together the groups which use them. 
There is a national interest, we are told, in the existence of harmonious criteria in philosophy, ethics and theology. In these days perhaps this argument is glossed over because again we have inherited inextricable difficulties from preceding centuries. Even where the theory of a harmonious outlook on life and religion rises above the crudest interpretations of the formula cuius regio, eius religio, it has attained only to the height of the national "genius." The national and mechanical state is religion enough for its subjects, if it could but have its way. So far as any portion of a people may subscribe to an international and supernatural religious faith, the force and vigor of the nationalism of that people is correspondingly weakened. An interest in religious unity, therefore, that is, the interest in the state regulation and measure of religious aspirations, would seem to be indispensable to the truly vigorous nation, but, fortunately for the human race, history gives no encouragement to those who make devotion to nationality synonymous with worship of the state. An interest there is in a religious harmony of strong convictions and intolerant not of faulty judgment and clouded vision, but rather of negation of principles, and of human pride. This interest, moreover, is one of nationality, but it is not an interest of nationalism. Its satisfaction calls for the fullest contribution by each race, by each individual, of the best in thought and character to the good of mankind. Such an interest can be assured by no national and material formulas; and those who seek to interpret it must sacrifice alike rationalism and nationalism. Every attempt to ignore religion and a moral conception of the universe and of the significance of life, has ended in sophism, in materialism, in decay, in horror. Every attempt to destroy or oppress the Catholic Church has made it more intensely distinct and international; every attempt to bend it to the uses of states and persons has been reacted against even more strongly by the innate vitality of religious conviction.

Again, the interest of a proper distribution of economic burdens presupposes a symmetrical and healthy development of commerce and industry in any one national group. "Self-sufficiency" and "economic independence" are the watchwords of today, significantly indicating our recrudescent emphasis upon nationalism. We are told, and it is true, no doubt, that a nation must produce, refine and distribute every element essential to the continuity and 
protection of its national integrity, material and spiritual. It would follow, therefore, that a real interest of nationality would be a well-rounded economic régime with not too much emphasis on any product-agricultural, mineral or manufactured-but rather a precise balancing of all the elements which go to make up a civilized community. In order that skill or natural advantage shall not again (as it is alleged they have done) cause us to grow unconscious from day to day of our racial barriers, it is proposed now to abrogate certain economic laws and to subordinate all rules, however familiar, to the superior interests of nationality. This call for economic solidarity is an inevitable accompaniment of nationalist movements. We have only to glance through history to find reaffirmation of our instinctive thought that the world and its civilization are a piece, both in duration and in extent; that as history is an uninterrupted causal chain, so the material world which we view at any given instant is an economic tableau constructed with an exquisite nicety and inter-relation which the human mind cannot grasp, much less succeed in altering by futile attempts at isolation of one or another portion.

Has nationality an interest in a uniform theory of government? It would seem that the concept of nationality, that is to say, the concept of identity of interests, necessarily involves unobstructed devising of the method by which nationality will fulfill, or at least express, its purpose in the world. Unless a people have an opportunity adequately to direct their own destiny regardless of their neighbors, they cannot serve as the model of a successful nation; and it is obviously impossible for the sense of direction of their destiny to be national unless this sense be accurately apprehended and interpreted. A uniform theory of government would seem, therefore, to be necessary; there must be a conviction that one method of government and one alone will correctly interpret and permit to be carried into effect the high designs and purposes of the nation. But again, too, history reassures us. The ideal of nationality would seem to have been far too much for weak human nature if it had involved the acceptance of a uniform theory of government, and above all of any particular theory of government, as an indispensable condition of its realization. Perhaps there is some truth in the statement that the more uniform the acceptance of any theory of government the less success judged from any point 
of view that theory will have of being carried into effect by that people. The history of human freedom is a history of human discipline, but not a discipline imposed by martinet or philosopher upon the individual. It is the record of contest between alternatives and the acceptance of either only after tested conviction. The minority is as likely to be right as the majority. Indeed, in the struggle for right the minority is more likely to be right than the majority, influenced as it must be by the gravity of the consequences of its contentiousness. It would seem, therefore, that again history shows itself indifferent to the categorical and inherent requirement of nationality that a people define and maintain a common theory of government. Whatever good the whole concept of nationality may have contributed to civilization and to the uplift of mankind has been accomplished with but little success in carrying into effect uniform theories of government. The consent of the governed or the rule of the best will in the future as they have in the past represent the widest divergence of views on the subject of government, and no aspiration of national integration will succeed in welding them. It is in their clash and contest that there lies the hope of progress of individual discipline and effort, of the eventual contribution by national and political units of the world to the cause of internationalism, of what today we may discern to have been contributed to the best nationalism by the divergent racial groups composing our various peoples.

For again, we repeat, history, that is, the world and its civilization, is of a piece in extension and in duration. The immutable truth which illuminates the thought and conduct of an individual is but a facet of the same eternal gem which energizes and inspires the racial and political unit. The truth of the humble worshipper of God is the truth of the majestic processes of international relations. The aspiration of the human soul to the eternal oneness of truth is what animates the noblest aspirations of nations; but our inarticulateness in transmitting thought and the material conditions of our common life render dark and uncertain the expression of those social and national thoughts and aspirations. The farmer tilling the rugged, reluctant soil of Castile, apprehends the nature of his task, and knows that to it he must adjust himself and his ways in order to escape failure. No less the nation must apprehend 
the laws which will govern its development, and realize how complete the disaster if these standards be not observed.

In the oneness of truth, in the universality of history, there is provided an ample satisfaction for all the aspirations of nationality. Wherein those aspirations reflect the light of truth, just so far does history record their providential transmutation into interests and their fulfillment, without recourse to the unsuccessful artifice of nationalism.

\section{"A MESSAGE FROM SYRIA" \\ By Mrs. Layyah A. Barakat, Philadelphia.}

I am a mere insignificant woman in the midst of this intelligent and scientific body, and I represent a little country-Syria - but I have a heart that has been given enlargement by the American Christians. I was only a barefooted Mount Lebanon girl. My father, my grandfather, my uncles and many of my people laid down their lives for their country. My people today are suffering under the yoke of the blood-thirsty and cruel Turks, and for all I know - for two years I haven't heard a word from my very own-my people have probably died from starvation, for no other reason than that they seek freedom and Christianity.

Syria is the country that gave you the Bible; Syria, the country that gave you the Christ; Syria, the cradle of Christianity. Before the discovery of America we had only one-half of the globe and we thought it was the whole world, and we looked to my little country as the very center of that world. To that center the Christ Jesus came; from that center the Christ sent his golden rule throughout the world. But since the discovery of America we have another half of the globe and we find America the new center. We expect the light to reflect back from this very center to our own, to send her Christ's golden rule, that Syria may have freedom and may have liberty, that Syria may be a democratic nation. They are longing for it. What can we do to help them?

I am one that was redeemed by the pennies of a Philadelphia Sunday School. It was the pennies that went to my native land from the hands of the consecrated American children that made me 